\title{
Déclaration de la Société européenne d'agronomie (ESA) adressée à la Commission européenne et relative à la réforme de la politique agricole commune
}

Les agronomes européens réunis à l'université d'Helsinki pour le $12^{\mathfrak{}}$ congrès de la Société européenne d'agronomie (ESA), fondée à Paris en décembre 1990, ont adressé à la Commission européenne une déclaration concernant la future réforme de la politique agricole commune. Cette déclaration en cinq points confirme que des mesures comme une plus grande diversité des cultures est de nature à améliorer les performances environnementales de l'agriculture.

Cependant, la seule mesure proposée qui concerne directement les pratiques agricoles (la "diversification "), ne produira pas d'amélioration significative de l'environnement dans la plupart des principales régions de production agricole d'Europe.

\section{Texte de la déclaration de la Société européenne d'agronomie}

The participants of the 12th Congress of the European Society for Agronomy at the University of Helsinki (20-24 August 2012), including 254 crop scientists from across the European Union and 30 from beyond its borders, have examined the European Commission's proposals to reform the Common Agricultural Policy. From this position, they:

1. Confirm that agronomic measures such as support for greater crop diversity can be used in CAP reform to improve the environmental performance of cropping systems. The potential benefits extend beyond the immediate crop environment. They encompass wider effects from reduced use of fertilisers and pesticides, increased farmland biodiversity, and global benefits from more diverse production. More diverse and resilient cropping patterns also have long-term agronomic and economic benefits. Diversification that encourages greater production of currently minor crops has the potential to reduce Europe's reliance on fossil energy, other non-renewable resources and imported plant protein.

2. Draw attention to the diversity of agro-ecological zones in Europe. A 'one-size-fits-all' approach constrains the development of measures that effectively support the sustainable development of cropping systems across Europe. The Commission should aspire to develop flexible but demanding agronomic measures targeted at regional environmental and resource protection challenges and opportunities.

3. Express concern that the 'diversification' measure, as currently proposed, will fail to deliver substantial change in most of Europe's major cropping areas. The threshold of $70 \%$ for any one species is already met in most farming systems. The scientists urge greater recognition of the well established benefits of taxonomic (e.g. different plant genera) and agronomic diversity and note that the diversification measure neither promotes that diversity, nor requires the rotation of crops, although many resource-protection and environmental benefits of crop diversification in annual cropping systems depend on it. They call for incentives for crop rotations that provide long-term agronomic and economic benefits. Measures to increase crop diversity in such rotations include using cover crops and intercrops, and increasing the production of currently minor crops, for example legumes (e.g. peas and beans).

4. Appeal to the Council of Ministers and the European Parliament to support a public debate about the development of European cropping systems in the context of CAP reform, and to grasp this opportunity to deliver reform that exploits the potential of changes in cropping systems to improve the productive base and environmental performance of European arable farming.

\author{
Pour en savoir plus : \\ http://www.european-agronomy.org/
}

